\title{
No escuro, os arqueólogos gostam de ficar em silêncio: o argumento do silêncio e a historicidade da anistia de Pilatos a Barrabás
}

\author{
In the dark, archaeologists like to stay in silence: \\ the argument of silence and the historicity of Pilate's \\ pardon to Barabbas
}

\section{En la obscuridad, a los arqueólogos les gusta quedarse en silencio: el argumento del silencio y la historicidad de la amnistía de Pilatos a Barrabás}

\author{
Milton L. Torres*
}

\begin{abstract}
RESUMO
Invoca-se, com frequência, o argumento do silêncio para colocar em dúvida a existência histórica de Jesus Barrabás, o personagem enigmático a quem, de acordo com os evangelhos, a turba preferiu libertar, em detrimento de Jesus Cristo. De fato, o personagem não é mencionado senão nos evangelhos. Tampouco se percebem referências históricas inequívocas ao costume romano ou judaico de se libertar um prisioneiro durante a páscoa, o assim-chamado privilégio pascoal. Este artigo pretende, portanto, analisar a força argumentativa desse duplo argumento do silêncio e apresentar um breve resumo da evidência geralmente apresentada por historiadores e arqueólogos contra e a favor do privilégio pascoal. Finalmente, o artigo propõe uma breve reflexão sobre o valor geral de um argumento do silêncio.

Palavras-chave: Barrabás; Argumento do silêncio; Privilégio pascoal.
\end{abstract}

\begin{abstract}
The argument of silence is often invoked to cast doubt on the historical existence of Jesus Barabbas, the enigmatic character whom, according to the Gospels, the mob preferred to release instead of Jesus Christ. In fact, the character is mentioned only in the Gospels. Besides, there is not a clear reference in our historical sources to the Roman or Jewish custom of freeing a prisoner during Easter, the so-called paschal privilege. This article intends, therefore, to analyze the argumentative force of this double argument of silence and to present a brief summary of the evidence generally adduced by historians and archaeologists against and in favor of the paschal privilege. Finally, the article proposes a brief discussion on the general value of an argument of silence.
\end{abstract}

Keywords: Barabbas. Argument of silence. Paschal privilege.

* Universidade Adventista de São Paulo (UNASP). Doutor em arqueologia clássica pela Universidade do Texas; doutor em letras clássicas pela USP; pós-doutor em estudos literários pela UFMG; professor do mestrado profissional em educação da Universidade Adventista de São Paulo (UNASP).

milton.torres@unasp.edu.br 


\begin{abstract}
RESUMEN
Se invoca con frecuencia el argumento del silencio para poner en duda la existencia histórica de Jesús Barrabás, el personaje enigmático a quien, de acuerdo con los evangelios, la turba prefirió liberar en detrimento de Jesucristo. De hecho, el personaje no se menciona sino en los evangelios. Tampoco se perciben referencias históricas inequívocas a la costumbre romana o judía de liberarse a un prisionero durante la pascua, el llamado privilegio pascual. Este artículo pretende, por lo tanto, analizar la fuerza argumentativa de ese doble argumento del silencio y presentar un breve resumen de la evidencia generalmente presentada por historiadores y arqueólogos en contra y en favor del privilegio pascual. Finalmente, el artículo propone una breve reflexión sobre el valor general de un argumento del silencio.

Palabras clave: Barrabás. Argumento del silencio. Privilegio pascual.
\end{abstract}

A referência evangélica ao assim chamado "privilégio pascoal", isto é, um suposto costume judaico de se libertar um prisioneiro na época da páscoa, mobiliza, já faz tempo, os estudiosos, tanto em defesa de sua autenticidade quanto em oposição a ela. Apesar de se tratar de uma possibilidade histórica, os historiadores e arqueólogos se sentem incapazes de comprová-la ou refutá-la. As fontes judaicas, quer em grego (como Josefo e Filo, por exemplo), quer em aramaico ou hebraico, não fazem qualquer referência explícita ao costume. Isso provoca a desconfiança de muitos estudiosos quanto à plausibilidade da narrativa evangélica da anistia de Barrabás, um relato encontrado nos quatro evangelhos (Mt 27,15; Mc 15,6; Lc 23,17; Jo 18,39), sendo que Mateus e João consideram o indulto mais um costume judaico, enquanto que Marcos e Lucas, este último com problemas crítico-textuais, o ligam mais à prerrogativa de Pilatos. Contudo, nenhuma dessas passagens reivindica a força legal de, por exemplo, Atos 25,16.

Bultmann (1972, p.272), por isso, declarou que “o episódio de Barrabás é, obviamente, uma expansão lendária cuja extensão não pode ser determinada com precisão". De fato, muitos outros estudiosos, desde o início do século, negaram a existência histórica do privilégio pascoal (HUSBAND, 1917, p.110116). Sobre essa narrativa evangélica ainda pesa a suspeita de que a passagem se revista de caráter simbólico, uma vez que o significado do nome hebraico do prisioneiro anistiado é "filho do pai" (bar-abbas), o que contribui para que ele apareça, no relato, como uma espécie de duplo de Jesus Cristo, descrito pelo evangelho de João como verdadeiro "Filho do Pai". Por essa razão, Couchoud e Stahl (1930, p. 140) chamaram a perícope de "episódio barroco" e Winter (1961, p. 94) a classificou como "um produto da imaginação".

De fato, o nome do prisioneiro varia na tradição manuscrita, onde aparece como Barabás, Barrabás, Barnabé e Babarrabás, sendo Barabás o mais comum de todos (RIGG JR., 1945, p. 434). Essa forma causa, porém, tanto desconforto que, ao comentar sua ocorrência em Mt 27,16, Jerônimo preferiu explicá-la da seguinte forma: 
Iste Barabbas in evangelio quod inscribitur iuxta bebreos, filius magistri eorum interpretatur, qui propter seditionem et homicidium fuerat condemnatus.

Esse [nome] Barabás, que, no evangelho, assim se escreve aproximadamente em hebraico, se traduz por "filho de seu mestre", aquele que foi condenado por tumulto e homicídio.

Lagrange (1911, p.387) considera muito menos provável, porém, a forma cuja etimologia Jerônimo imagina como proveniente de Barambás. ${ }^{1} \mathrm{Um}$ escoliasta de Orígenes explicou essa formação alternativa e concluiu sua explicação com uma pergunta retórica:

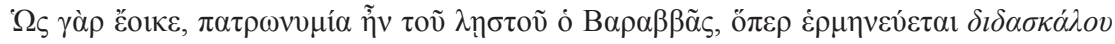

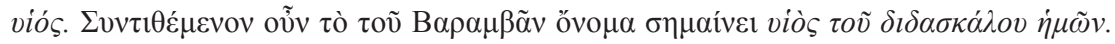

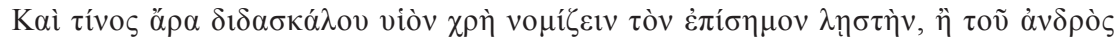

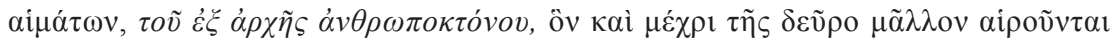

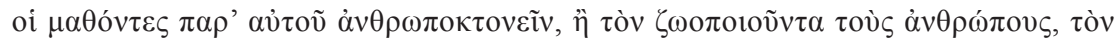

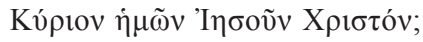

Ao que parece, o sobrenome do bandido era Barabás, que se interpreta como "filho do mestre", pois, como substantivo composto, o nome de Barambás significa "filho de nosso mestre". Ora, devemos considerar o notório salteador como filho de que mestre? Do homem de sangue, que era, desde o princípio, homicida, aquele de quem, até hoje, aprendem-se homicídios? Ou será que é de nosso Senhor Jesus Cristo, Aquele que vivifica as pessoas?

Mas o próprio Jerônimo, em sua obra sobre a tradução dos nomes hebraicos, dá a interpretação que deve ser considerada a mais correta e provável:

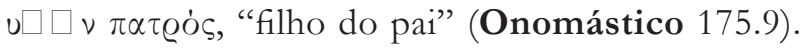

Por essas considerações, e segundo se deduz do evangelho de João, é Cristo que deveria ser chamado de Barrabás (COUCHOUD; STAHL, 1930, p.139). Apesar disso, o prisioneiro anistiado não somente é chamado de Barrabás, mas de Jesus Barrabás! Apenas seis manuscritos gregos trazem o primeiro nome de Barrabás em Mt 27,16, nenhum dos quais anterior ao séc. 9, mas é fácil imaginar que tenha havido uma omissão generalizada desse nome, pois, de acordo com Lagrange (1923, p. 520), os cristãos primitivos achavam ofensivo dar esse nome a uma pessoa irreligiosa e seria inconcebível que um copista houvesse acrescentado o nome de Jesus a Barrabás. Omanson (2010, p. 50) até acha possível que tenha havido um acréscimo acidental do nome Jesus em Mt 27,17, por causa da ocorrência, nesse verso, do pronome

\footnotetext{
De acordo com Rufino (Apologia 2.20), por uma interessante coincidência, Jerônimo tinha um secretário chamado Baranina, que seus opositores chamavam de Barabás, sob a alegação de que a ele se deviam os hebraísmos da Vulgata.
} 
pessoal YMIN, com o qual pode ter sido confundido, mas não oferece nenhuma justificativa para outra inclusão no verso seguinte. Portanto, é melhor supor que o nome Jesus Barrabás seja original ao evangelho de Mateus.

No entanto, não se cita, como impedimento para a autenticidade do episódio, apenas a conexão simbólica que une o nome do criminoso a Jesus Cristo. O argumento mais grave vem do fato de que não se encontra na antiga literatura judaica nenhum vestígio claro do costume de se conceder indulto, durante a festa pascoal, a um prisioneiro condenado à morte. De fato, já no séc. 3, Orígenes (185-254 A.D.), ao comentar Mateus 27,15-26, explicou o privilégio pascal como sendo um costume judaico que não estava mais em vigor:

Tamen consuetudo haec aliquando fuit apud Iudaeos: Saul enim non interfecit Ionatham, omni populo petente eum ad vitam.

No entanto, esse costume existiu outrora entre os judeus, pois Saul não matou Jônatas, quando o povo todo intercedeu por sua vida.

As palavras de Orígenes, especialmente o advérbio aliquando ("outrora”), passam a nítida impressão de que esse escritor cristão primitivo se via às voltas com opositores que duvidavam, já na sua época, da historicidade do privilégio pascoal. Aliás, a primeira menção extrabíblica a Barrabás vem justamente de Orígenes, antes do qual há um absoluto silêncio acerca dessa personagem (RIGG JR., 1945, p. 433).

\section{Hipóteses favoráveis à historicidade do privilégio pascoal}

Conforme dito antes, os estudiosos vêm se mobilizando nos dois grandes lados do problema do privilégio pascoal: aqueles que defendem sua autenticidade e aqueles que o consideram como uma invenção cristã. $\mathrm{Na}$ tentativa de salvar a historicidade da narrativa, já em 1898, Wendland (apud COUCHOUD; STAHL, 1930, p.146) propunha que Jesus havia sido executado como rei da Saturnália, um costume romano de suposta antiguidade, segundo o qual se escolhia um prisioneiro ao acaso, que era tratado como realeza durante um mês, até ser sacrificado no altar de Saturno. Wendland chegou a comparar o costume com o texto de Filo (Contra Flaco 36-39), no qual o filósofo menciona que, certa vez, a ralé de Alexandria tomou um homem demente chamado Carabás e o vestiu com roupas reais improvisadas a fim de debochar do rei Agripa. Frazer (1900, p.186-198), por sua vez, em um apêndice de sua famosa obra $O$ ramo de ouro, especulativamente relacionou o episódio de Barrabás a um festival parecido com a Saturnália, entre 
os babilônios. Porém, essas suposições esbarram num insuperável obstáculo: os judeus jamais consentiriam com um sacrifício humano em Jerusalém (COUCHOUD; STAHL, 1930, p.148).

Cook (apud CHAVEL, 1941, p. 274) propôs que o privilégio pascoal tivesse se originado da benevolência romana. Em sua interpretação, os romanos teriam instituído o indulto para demonstrar sua simpatia pelos judeus e expressar apoio à sua principal festividade religiosa. O problema é que a única referência romana que conecta o indulto a uma festa religiosa não nos diz que este era, de fato, um costume, nem garante que a anistia era permanente. Trata-se, em vez disso, de uma etiologia da própria festa, o lectistérnio:

Duumviri sacris faciundis, lectisternio tunc primum in urbe Romana facto, per dies octo Apollinem Latonamque et Dianam, Herculem, Mercurium atque Neptunum tribus quam amplissime tum apparari poterat stratis lectis placauere. Privatim quoque id sacrum celebratum est. Tota urbe patentibus ianuis promiscuoque usu rerum omnium in propatulo posito, notos ignotosque passim advenas in hospitium ductos ferunt, et cum inimicis quoque benigne ac comiter sermones habitos; iurgiis ac litibus temperatum; vinctis quoque dempta in eos dies vincula; religioni deinde fuisse quibus eam opem di tulissent vinciri.

Quando o lectistérnio foi introduzido na cidade de Roma, os duúnviros encarregados dos assuntos religiosos imploraram, durante oito dias, o favor de Apolo e Latona, Diana e Hércules, Mercúrio e Netuno. Para isso, três poltronas foram preparadas com a maior magnificência que era, então, possível. O mesmo rito solene foi observado pelos indivíduos comuns. As portas ficaram abertas por toda a cidade e as pessoas puderam fazer uso dos bens alheios. Dizem que todos os que passavam pela cidade, quer conhecidos, quer não, foram convidados às casas e que até aquelas pessoas que não tinham muito jeito para a cortesia e a bondade participaram das conversas. Ninguém brigou, nem discutiu. Também tiraram as correntes dos que estavam presos durante aqueles dias. Depois, todos tiveram vergonha de voltar a prender aqueles que os deuses tinham socorrido (Tito Lívio, História de Roma, livro 5, parágrafo 13, linhas 5 a 8).

Dionísio de Halicarnasso repete, em suas Antiguidades romanas (12.9), essa mesma informação sobre o primeiro lectistérnio na metrópole:

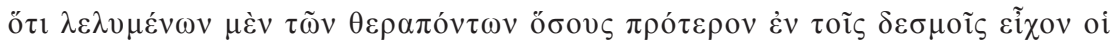

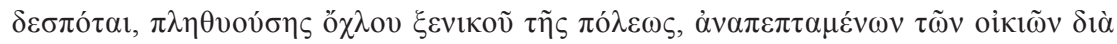

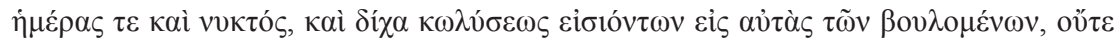

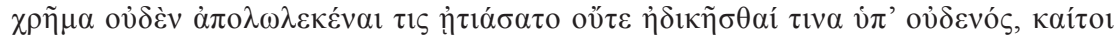

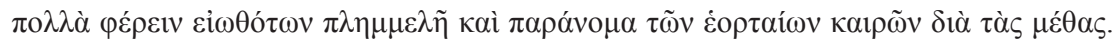

que, embora todos os escravos que, antes, os mestres tinham em correntes fossem libertados, embora a cidade se enchesse de uma multidão de estrangeiros, embora as casas permanecessem abertas de dia e de noite, embora todos que quisessem entrassem 
nelas sem impedimento, ninguém reclamou de perder um bem sequer ou de ter sido prejudicado por outra pessoa, apesar de a ocasião das festas geralmente propiciar muitas coisas inconvenientes e ilegais por causa da embriaguez.

Como toda a teoria de Cook e de outros estudiosos que o seguiram repousa sobre essa passagem de Lívio repetida por Dionísio, parece que lhes faltou suficiente evidência para levá-la além do campo da especulação. Além disso, de acordo com Crossan (1995, p. 141), atribuir aos romanos a iniciativa de libertar um prisioneiro judeu contradiz expressamente o perfil de Pilatos traçado por Josefo e a descrição empreendida por Filo, em Contra Flaco 81-84, das anistias romanas, segundo a qual os prisioneiros eram poupados temporariamente durante as festas, sendo executados logo após o seu término:

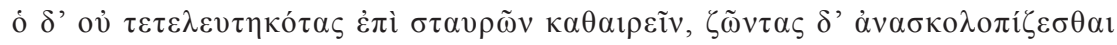

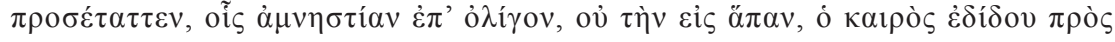

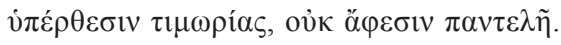

Ele [Flaco] não mandou retirar os mortos da cruz, mas crucificar os vivos, aos quais a ocasião concedia uma anistia temporária, mas não definitiva, pelo adiamento do castigo, embora não um perdão completo.

$\mathrm{Na}$ passagem, Filo deplora o fato de Flaco, governador do Egito, não ter seguido o protocolo das anistias temporárias durante as comemorações do aniversário do imperador Calígula, no dia 31 de agosto do ano 38.

Diante de outra hipótese que alegava que o referido costume do privilégio pascoal teria sido uma herança do período de dominação grega, Merritt (1985, p. 63) menciona que os gregos raramente mantinham os criminosos em cárcere, preferindo outras penas, como a execução, o exílio, o confisco de bens, as multas e a perda de estatuto social. Além disso, Ulpiano, escoliasta de Demóstenes (22.68), nos informa que, nos raros casos em que ocorria, o indulto era apenas temporário e não havia uma anistia total. Por isso, foram raros os casos de indulto, estes ficando praticamente restritos à Grande Dionisíaca, à Crônia (equivalente grego da Saturnália romana) e a alguns outros importantes festivais, como a procissão panatenaica e as Tesmofórias (cf. PLUMMER, apud CHAVEL, 1941, p. 274).

Outros cogitaram que o privilégio pascoal pudesse ter sido uma invenção de Herodes (CHAVEL, 1941, p. 274). Houve até quem supusesse que o silêncio dos judeus acerca do privilégio pascoal fosse um caso de lapso intencional do Talmude, ou por não o considerar um tema apropriado ou para desacreditar o relato evangélico (LANGE apud CHAVEL, 1941). Um copista antigo acrescentou, no códice IX.47, a seguinte glosa à passagem: 


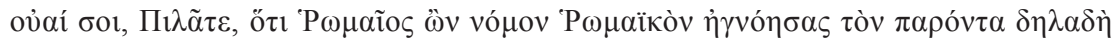

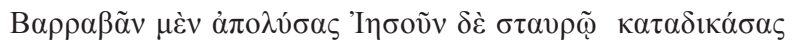

ai de ti, Pilatos, que, sendo romano, claramente não fizeste caso da vigente lei romana ao libertar Barrambás e condenar Jesus à cruz.

Trata-se, entretanto, de manuscrito tardio, sem grande peso como evidência.

\section{Argumentos contra a autenticidade do privilégio pascoal}

Com base na suposição do silêncio das fontes judaicas, vários argumentos foram levantados contra a historicidade do privilégio pascoal, entre eles o argumento mitológico, o argumento tipológico, o argumento de identificação e o argumento da apologia.

Estudiosos como Heinrich Zimmern (apud COUCHOUD; STAHL, 1930, p. 148-149), por exemplo, preferiram explicar o episódio de Barrabás como uma mitologia desenvolvida pelos cristãos por influência dos rituais de paixão representados nas religiões semíticas. Desde a publicação, em 1918, de um texto encontrado nas escavações de Assur, sabe-se que os antigos semitas contavam com um mito da paixão de Bel-Marduque, importante divindade dos babilônios, no qual o deus é aprisionado, levado para uma montanha, questionado, flagelado, traspassado e morto para ser, algum tempo depois, ressuscitado por sua esposa Ishtar. De modo semelhante, Landsberger (apud MERRITT, 1985, p. 57-68) se referiu a um mito babilônico no qual o rei recitava um salmo penitencial e libertava um prisioneiro, assim promovendo uma reversão no estatuto social. De acordo com Landsberger, essa antiga mitologia poderia ter servido de paradigma para o relato evangélico no qual o Messias penitente assume sobre si a pena que era devida ao criminoso culpado. Note-se que, embora Marcos e Mateus se refiram ao assim chamado "privilégio pascal" como prática romana, João o chama de "costume judaico". Argumenta-se, portanto, que a referência joanina sugira que os judeus tinham sido expostos a essa prática durante seu cativeiro babilônico, o que teria facilitado sua apropriação do tema e aplicação por parte dos evangelistas.

De modo geral, os estudiosos que optaram por uma origem mitológica para o privilégio pascoal entendiam que os evangelistas conheciam a prática generalizada, no mundo pagão, de indultos especiais por ocasião das festas públicas e estavam familiarizados, além disso, com a prática costumeira, nas competições entre gladiadores, de a maior autoridade presente tomar a decisão se a vida do lutador era preservada ou não e, por isso, teriam lançado mão dessa explicação para culpar os judeus (AUS, 1998) e isentar os romanos 
da condenação de Jesus (MERRITT, 1985, p. 68). Segundo eles, a suposta interpolação desse relato deve ter ocorrido depois do período de vida dos apóstolos, quando os primeiros cristãos desejaram se distanciar dos judeus e se aproximar dos gentios.

Arthur Drews (apud COUCHOUD; STAHL, 1930, p. 150) propôs um argumento tipológico segundo o qual o duplo Jesus Cristo/Jesus Barrabás nada mais era do que uma encenação de um ritual duplo da Bíblia Hebraica: o rito do bode expiatório e do bode emissário de Lv 16,7-10. Para isso, o erudito buscou apoio em algumas citações da literatura cristã primitiva que enfatizavam o papel de Jesus como bode expiatório. A Epístola de Barnabé 7,10, por exemplo, faz a seguinte declaração, consoante com $\mathrm{Hb} 9,28$ :

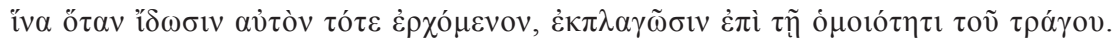

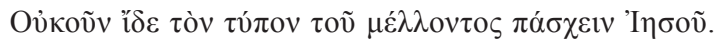

para que, quando o vejam voltar, se admirem da semelhança com o bode. Eis, de fato, um tipo do que o vindouro Jesus sofreu.

Um grupo de estudiosos defendeu o argumento da identificação, isto é, a ideia de que Jesus Barrabás era, nada mais, nada menos, do que o próprio Jesus Cristo. Rigg Jr. (1945, p. 428-432) teve a ideia, que foi independentemente desenvolvida por Maccoby (1969, p. 55-60) e suplementada por Davies (1981, p. 260-262). Essa suposição repousa na informação fornecida por Jerônimo, em sua epístola 10 a Dâmaso, de que, durante a entrada triunfal de Jesus em Jerusalém, o povo teria cantado Osana Baramá, fazendo com que Baramá (mais tarde, Barabás) se tornasse um apelido de Cristo. ${ }^{2}$ Nesse caso, Jesus de Nazaré teria sido conhecido por seus contemporâneos como Jesus Barabás e não existiria uma pessoa diferente de nome Barrabás. Portanto, Pilatos não teria proposto uma escolha entre dois prisioneiros para que um fizesse jus ao privilégio pascoal. Nessa concepção, Jesus simplesmente teria sido julgado duas vezes por Pilatos (SHERWIN-WHITE, 1965, p. 35). Na primeira vez, na condição de Barrabás, "filho do Pai”, ele teria sido absolvido, pois não havia nenhuma lei romana que proibia que uma pessoa se considerasse divina. No entanto, na segunda vez, como Cristo, Jesus teria sido condenado, pois se apresentar como "rei dos judeus" (Mc 15,9 e Jo 18,39) era crime passível de pena capital. Portanto, não seria um caso de duas pessoas sob julgamento, mas de uma mesma pessoa ser julgada duas vezes.

Os que se opõem à historicidade da passagem, geralmente defendem o argumento da apologia, a ideia de que o episódio foi inventado pelos cristãos

O livro apócrifo conhecido como Atos de Pilatos registra, porém, um clamor ligeiramente diferente. 
com o intuito de isentar as autoridades romanas de seu papel como executoras de Cristo e, assim, enfatizar a inocência de Jesus, assassinado pelos judeus em um procedimento sem respaldo legal e à revelia das autoridades romanas. Teria, portanto, a mesma função apologética da lavagem de mãos por parte de Pilatos. No caso, por exemplo, da análise de Couchoud e Stahl (1930), a preocupação seria mostrar que o evangelho de João é mais antigo do que a tradição sinótica. Por isso, o episódio de Barrabás é evocado como prova desse fato, sendo considerado apenas como uma ficção cristã para desacreditar a ideia, disseminada em alguns círculos, de que Jesus não havia sido realmente crucificado. Nessa concepção, o trecho teria a intenção de refutar, por exemplo, a crença herética de que Simão Cireneu teria tomado o lugar de Jesus na cruz, conforme afirmava Basílides e segundo registrou Irineu (Contra as heresias 1.24.4):

Quapropter neque passum eum, sed Simonem quendam Cyrenaeum angariatum portasse crucem ejus pro eo: et bunc secundum ignorantiam et errorem crucifixum, transfiguratum ab eo, uti putaretur ipse esse Jesus et ipsum autem Jesum Simonis accepisse formam, et stantem irrisisse eos.

Portanto, Ele [Jesus] não sofreu, mas Simão, certo homem de Cirene, foi forçado a carregar a cruz em seu lugar; e foi este segundo que foi transfigurado por Jesus para que pensassem que era Jesus e, por ignorância e erro, foi crucificado. Mas Jesus mesmo tomou a forma desse Simão e ficou de lado, rindo deles.

Os argumentos contra a autenticidade do privilégio pascoal não aparecem, na maioria das vezes, como categorias isoladas. Em vez disso, o que ocorre é uma mistura entre as mesmas. Assim, por exemplo, o argumento da apologia também inclui a possibilidade de uma identificação de Jesus Barrabás com Jesus Bar Kochba, o líder messiânico da época do imperador Adriano. Segundo essa hipótese de Tuccinardi (201?), esse revolucionário de historicidade comprovada teria servido de inspiração para que os cristãos, em seu esforço apologético, imaginassem a figura de Jesus Barrabás para servir de sustentação histórica para uma duvidosa autenticidade do julgamento e condenação de Jesus Cristo. Como se percebe, então, devido ao fato de os estudiosos se sentirem no escuro, sem muita perspectiva de resolução do problema do privilégio pascoal, o argumento do silêncio contribuiu para a criação de uma série de teorias explicativas, com base em evidência escassa. $\mathrm{O}$ debate se trava principalmente entre teólogos, historiadores e filólogos, pois os arqueólogos parecem preferir ficar em silêncio, quando estão no escuro.

\section{A persistência do argumento do silêncio}

Em geral, argumentos do silêncio têm a sua importância, mas não devem ser excessivamente valorizados. Talvez, mais do que os demais estudiosos, 
os arqueólogos compreendam a natureza acidental e contingente do registro arqueológico e, por isso, desconfiem desse tipo de argumento. Mesmo os historiadores, há muito reconhecem esse fato. Em todos os casos, os argumentos devem se basear preferencialmente na evidência:

Várias razões podem ser propostas para apoiar uma declaração sobre eventos passados,
como referências a tendências comuns à época, leis empíricas, generalizações estatísticas,
costumes relevantes e o caráter dos indivíduos; mas, mais comumente, o raciocínio
historiográfico depende de declarações de evidência - declarações que ocorrem, ou
estão implícitas, em documentos provisoriamente autenticados, como diários, cartas,
memórias, jornais, relatórios ou inscrições. A conclusão típica do historiador é princi-
palmente uma função de declarações da evidência aceita [...]. Paradoxalmente, contudo
[...], o argumento do silêncio não depende de declarações de evidência. Numa primeira
abordagem, pode-se dizer que o argumento do silêncio pretende provar que uma dada
alegação A é falsa ou não merece crédito, porque aceitáveis declarações de evidência
não existem para dar apoio a A (LANGE, 1966, p. 288).

O problema é auferir que quantidade de ruído é suficiente para quebrar o silêncio. Ou seja, quando podemos estar certos, além de qualquer dúvida razoável, de que há evidência para contrariar o argumento do silêncio? No caso do privilégio pascoal, parece que dois itens de evidência sugerem que o argumento do silêncio se provou menos atraente do que se pensava: a pesquisa do rabino polonês Charles Ber Chavel (1908-1996) e uma inscrição da época do imperador Domiciano.

Chavel investigou a Mishnah, uma das principais obras do judaísmo rabínico no início da era cristã, e descobriu que o tratado Pesahim 91a continha uma alusão, embora bastante breve e vaga, a uma anistia durante a páscoa. O rabino oferece a seguinte leitura da passagem:

Para uma pessoa de luto, para alguém que esteja removendo um monturo (que desmoronou sobre alguém) e, igualmente, para alguém que recebeu a promessa de indulto, para o inválido e para o idoso que só consegue comer uma azeitona, alguém deve oferecer o sacrifício. Contudo, nesses casos, não se deve sacrificar só para eles, a fim de que não contaminem o sacrifício da páscoa.

As especificações da regra têm que ver com o fato de que o enlutado está cerimonialmente impuro por causa de seu contato com o morto; o que desenterra a pessoa pode ficar impuro se a pessoa soterrada for encontrada morta; o prisioneiro pode não ser, afinal, libertado; e o inválido e o idoso podem não ter forças para comer o sacrifício. Por essa razão, é necessário que sejam incluídos no sacrifício realizado por outras pessoas. 
De acordo com Chavel (1941, p.275-276), o regulamento se refere a dois tipos de impedimentos à participação na páscoa: limitação legal e limitação física. No primeiro caso (enlutado, escavador e prisioneiro), a impureza cerimonial proíbe a participação; no segundo caso (idoso e inválido), o fato de o participante não estar apto a ingerir o sacrifício também serve de impedimento. De qualquer forma, na parte que mais nos interessa, o texto se refere a um prisioneiro hebreu a quem tenha sido prometido indulto, pois a regra especifica sua participação ou não no sacrifício da páscoa, cujo requerimento principal era o de um estatuto hebreu. Ou seja, os estrangeiros inconversos não podiam participar do sacrifício, o que exige que o prisioneiro em questão seja judeu.

Além disso, sabe-se que as leis judaicas admitiam poucas exceções e, por essa razão, Chavel postula que o prisioneiro em questão seria encarcerado por uma autoridade estrangeira, quer grega, quer romana. Para provar sua suposição, Chavel (1941, p. 276) apresenta um comentário de um sábio palestino do séc. 3, conhecido como R. Johanan a respeito desse regulamento:

Rabbah, filho de R. Huna disse em nome de R. Johanan: os sábios interpretavam esta [Mishnah] somente em referência a uma prisão pagã; mas se o cárcere é israelita, alguém deve fazer o sacrifício em separado, já que lhe foi prometido e ele será [sem dúvida] libertado, conforme está escrito: “o remanescente de Israel não praticará a iniquidade, nem proferirá mentiras” [Sofonias 3:13].

Portanto, temos duas fontes antigas que mencionam o privilégio pascoal, ambas apontando para a natureza judaica do costume e ambas considerando a possibilidade de que o costume se estenda ao caso de o prisioneiro estar sob uma autoridade estrangeira em território israelita.

O rabino Chavel chega a três importantes conclusões, com base nas fontes hebraicas em que realizou sua pesquisa: que o costume tinha um vínculo positivo com a tradição judaica; que já era praticado no período pré-romano; e que sua aplicação incidia sobre prisioneiros políticos. Para ele, os líderes judaicos tinham uma motivação financeira para a instauração e manutenção desse costume. Eles sabiam que

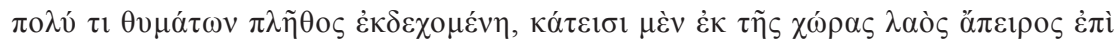

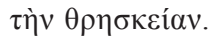

[a páscoa] aguardava uma grande quantidade de sacrifícios, pois uma inumerável multidão vinha do campo para a cerimônia (Josefo, Guerras judaicas 2.1.3). 
Em tempos de dominação estrangeira, a peregrinação a Jerusalém era dificultosa e o privilégio pascoal funcionava como mais um incentivo a que os peregrinos viessem à cidade e, com sua presença, proporcionassem muitos lucros aos cambistas do templo.

Outra evidência contra o argumento do silêncio, embora exígua, vem de um papiro florentino (P. Flor. 61) do ano 85, mencionado por Deissmann (1927, p. 269-270), no qual G. Septímio Vegeto, governador do Egito, se dirige a um tal Fobião, que havia sido julgado por ele em um procedimento legal no qual fora acusado de manter um de seus supostos devedores em cárcere privado:

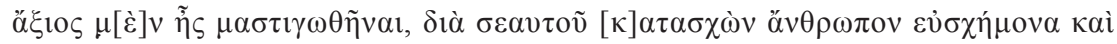

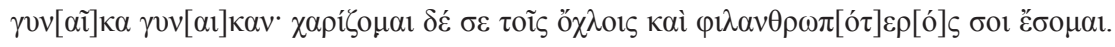

Você merecia ser flagelado, por prender um homem decente e sua esposa, mas eu entrego você à multidão e, assim, lhe demonstrarei minha grande misericórdia.

Apesar de não expressar, em palavras inequívocas, que o réu seria posto à mercê de uma decisão da populaça, nem tampouco conectar a anistia a uma festa popular, muito menos indicar uma escolha entre dois ou mais condenados, o texto fornece o precedente de uma autoridade romana de jurisprudência local anistiar um prisioneiro evidentemente culpado.

\section{Considerações finais}

Da maneira como queiramos interpretar o relato do privilégio pascoal, se não há, além de qualquer dúvida, um relato judaico de um indulto oferecido aos criminosos por ocasião de um festival importante, há precedentes sumérios, babilônicos, assírios, hititas, gregos e romanos, embora separados entre si por milhares de anos (MERRITT, 1985, p. 57-68).

Apesar de não haver nenhuma evidência concreta de que os judeus tenham herdado o costume do indulto de fontes babilônicas, temos notícia de pelo menos um judeu que se beneficiou dessa prática antiga. Trata-se de Joaquim, rei de Judá, que foi indultado por Amel-Marduque (isto é, Evil-Merodaque), após a morte de Nabucodonosor (2 Reis 25,27-30; Jr 52,31-34).

$\mathrm{O}$ argumento do silêncio tem o seu valor, mas é, em geral, extremamente difícil impor limites à sua validade e alcance. No caso do privilégio pascoal, parece que continuamos todos no escuro. Nessas horas, talvez seja mais prudente ficar em silêncio do que vocalizar a opinião de que o silêncio prove qualquer outra coisa além de sua própria existência. Mesmo no escuro, porém, podemos procurar ouvir e, quando isso acontece, é possível captar, em meio ao silêncio, algum ruído distante. 


\section{Referências bibliográficas}

AUS, R.D. Caught in the act: walking on the sea, and the release of Barabbas revisited. Atlanta, GA: Scholars, 1998.

BULTMANN, R. The history of the Synoptic Tradition. Oxford: Blackwell, 1972.

CHAVEL, Charles B. The releasing of a prisoner on the eve of Passover in ancient Jerusalem. Journal of Biblical Literature, vol. 60, n. 3, p. 273-278, 1941.

COUCHOUD, P.-L.; STAHL, R. Premiers écrits du Christianisme. Paris: Rieder, 1930.

CROSSAN, John Dominic. Jesus: a revolutionary biography. New York: HarperCollins, 1995.

DAVIES, Stevan L. Who is called Bar Abbas? New Testament Studies, vol. 27, n. 2, p. 260262, 1981.

DEISSMANN, Adolf. Light from the ancient East. London: Hodder \& Stoughton, 1927.

FRAZER, James G. The golden bough. 2. ed. London: MacMillan, 1900.

HUSBAND, Richard W. The pardoning of prisoners by Pilate. The American Journal of Theology, vol. 21, n. 1, p. 110-116, 1917.

LAGRANGE, Marie-Joseph. Évangile selon saint Marc. Paris: J. Gabalda, 1911.

LAGRANGE, Marie-Joseph. Évangile selon saint Matthieu. Paris: Victor Lecoffre, 1923.

LANGE, John. The argument from silence. History and Theory, vol. 5, n. 3, p. 288-301, 1966.

MACCOBY, H.Z. Jesus and Barabbas. New Testament Studies, vol. 16, n. 1, p. 55-60, 1969.

MERRITT, Robert L. Jesus Barabbas and the paschal pardon. Journal of Biblical Literature, vol. 104, n. 1, p. 57-68, 1985.

OMANSON, Roger L. Variantes textuais do Novo Testamento: análise e avaliação do aparato crítico de o Novo Testamento grego. Barueri, SP: Sociedade Bíblica do Brasil, 2010.

RIGG, JR., Horace A. Barabbas. Journal of Biblical Literature, vol. 64, p. 428-432, 1945.

SHERWIN-WHITE, A. N. Roman society and Roman law in the New Testament. Corrected reprint. Oxford: Clarendon, 1965.

TUCCINARDI, Enrico. Barabbas dans l'histoire. 2010? Disponível em: https://www.academia.edu/14384134/Barabbas_dans_lHistoire. Acesso em: 25 ago 2017.

WINTER, P. On the trial of Jesus. Berlin: de Gruyter, 1961. 